\title{
Article \\ The Expressive Function of the ni que Insubordinate Construction in Spanish
}

\author{
Elena Martínez Caro ${ }^{1, *(1)}$ and Laura Alba-Juez ${ }^{2}$ \\ 1 Department of English Studies, Universidad Complutense, 28040 Madrid, Spain \\ 2 Foreign Languages Department, Universidad Nacional de Educación a Distancia, 28040 Madrid, Spain; \\ lalba@flog.uned.es \\ * Correspondence: elenamc@ucm.es
}

Citation: Martínez Caro, Elena, and Laura Alba-Juez. 2021. The Expressive Function of the ni que Insubordinate Construction in Spanish. Languages 6: 161. https:// doi.org/10.3390/languages6040161

Academic Editors: Renata Enghels, Fien De Latte and Linde Roels

Received: 4 June 2021

Accepted: 22 September 2021

Published: 8 October 2021

Publisher's Note: MDPI stays neutral with regard to jurisdictional claims in published maps and institutional affiliations.

Copyright: (c) 2021 by the authors. Licensee MDPI, Basel, Switzerland. This article is an open access article distributed under the terms and conditions of the Creative Commons Attribution (CC BY) license (https:// creativecommons.org/licenses/by/ $4.0 /)$.
Abstract: Authors such as Tyler Schnoebelen (on page 12 of his study Emotions are Relational: Positioning and the Use of Affective Linguistic Resources), suggest that in some languages (cf. Navajo), certain dependent clauses are frequently used independently to "mark emotional evaluation and background information". Evans, in his work on insubordination and its uses, makes use of the term insubordination to refer to this phenomenon. Our study focuses on a particular insubordinate construction introduced by the sequence ni que in Spanish, as in the example [iUna carta cada día!] Ni que yo fuese Umbral. (CORPES Corpus), used as an independent clause with a sociopragmatic meaning, which is different from that of its subordinate counterpart (cf. No escribiría una carta cada día ni que yo fuese Umbral). Our research questions ask about the potential for ni que to be used as a discourse marker fulfilling an expressive function when it introduces this type of construction, and the derived hypothesis is then oriented to test whether Schnoebelen's observation about insubordinate constructions also applies to this Spanish construction. In order to test this hypothesis, we performed a functional discourse analysis of more than 2000 concordances (and their extended contexts) in Mark Davies' Corpus del Español and the Real Academia CORPES XXI. Our findings show that the insubordinate construction differs in function and meaning from its subordinate counterpart, the former fulfilling an emotive function, often combined with other discourse-pragmatic functions, such as evaluation or the organization of discourse.

Keywords: insubordinate constructions; the expressive function of language; language and emotion; ni que construction in Spanish

\section{Introduction}

In recent decades, linguistics has witnessed an increasing interest in the expressive function of language (as opposed to its referential function; cf. Foolen (2016)) and the related areas of subjectivity and stance (cf., e.g., (Biber et al. 1999; Englebretson 2007; Thompson and Alba-Juez 2014)). A speaker's subjectivity can be manifested in various ways linguistically and non-linguistically, from the numerous forms of body language to the reflection of subjectivity in the different levels of linguistic analysis. The area of subjectivity itself and the expressive meaning of language can refer to different forms of communication, such as the obvious expression of feelings, and other associated meanings such as affective states, attitudes, beliefs, value judgements and assessments (Baumgarten et al. 2012; Foolen 2016).

A wide range of linguistic structures have received attention in the literature related to this set of linguistic meanings. Among these, authors such as Schnoebelen (2012, p. 12) suggest that in some languages (cf. Navajo) certain dependent clauses are frequently used independently to "mark emotional evaluation and background information". Evans (2007) uses the term insubordination to refer to this phenomenon. He defines it as "the conventionalized main clause use of what, on prima facie grounds, appear to be formally 
subordinate clauses" (Evans 2007, p. 367), or, in more simple terms, "as the independent use of constructions exhibiting prima facie characteristics of subordinate clauses" (Evans and Watanabe 2016b, p. 2). Even when they have often been marginalized in grammars, they "turn out to be surprisingly widespread" (Evans and Watanabe 2016b).

This study intends to broaden the present discussion of subjectivity and stance by focusing on an understudied type of insubordinate construction in Spanish-that introduced by the sequence ni que-as in the following examples:

1.a. ¡Una carta cada día! Ni que yo fuese Umbral.

'A letter everyday! As if I were Umbral'.

(CORPES 100. ¿La pareja? Bien, gracias", El Club de la Comedia) ${ }^{1}$

b. Dámela, hombre. Ni que me tuvieras miedo.

'Give it to me, for goodness sake. As if you were afraid of me'.

(CdE 86. Gran Señor y Rajadiablos, Eduardo Barrios)

The highlighted clauses in (1) exhibit certain characteristics associated with a subordinate clause, the use of the sequence ni que containing the subordinating conjunction que and the subjunctive verbal form tuvieras; yet, they are used independently, that is, without the accompanying main clause. Thus (1a), for instance, is different from its subordinate counterpart, presented in (2):

2. No escribiría una carta cada día ni que yo fuese Umbral.

'I would not write a letter every day even if I were Umbral'.

Leaving apart the syntactic properties of both, an important difference between (1a) and (2) lies in the semantic-pragmatic meaning of the construction in (1a), as compared to (2). Thus, the two examples of this construction in (1) convey an expressive meaning that goes beyond the mere representational, or truth-conditional meaning, and that is absent from their subordinate counterparts (as shown in 2). In (1a-b) the purpose of the utterances is not to convey some new information (i.e., it is obvious that the speaker is not the well-known Spanish writer Umbral (1a) and that the addressee is not afraid of the speaker (1b)) but to transmit a purely expressive meaning, by presenting an impossible presupposition that is emphatically negated.

In studies of insubordination in Spanish, where the Spanish term insubordinación is often not used, research has mainly focused on sentences introduced by que, como and si (cf., e.g., Rodríguez Ramalle 2011, 2015; Sansiñena 2015; Sansiñena et al. 2015; Gras 2011, 2016; Gras and Sansiñena 2015; Porroche 2000a, 2003). To the best of our knowledge, there are no studies on the insubordinate construction in Spanish introduced by ni que alone; see, however, Porroche (2000b), who explores different discourse uses of the marker $n i$ in Spanish, including among others the insubordinate use, and Gras (2007) who studies the subordinate ni que clause. By and large, very little has been said to date about the capacity of the ni que sequence in Spanish to function as an expressive discourse marker (Porroche 2015) introducing an insubordinate sentence.

The present paper will discuss aspects of the expressive meaning of this construction as a reference to an imaginary, unreal world, which is presented as impossible and emphatically negated, generally by pragmatic means such as the triggering of a counter-factive presupposition. In a wider perspective, this contribution aims to shed light onto one of the areas related to insubordination suggested by Evans and Watanabe (2016b) in their review chapter on insubordination, namely how corpus-based approaches can provide a more accurate picture of "what is happening with particular insubordinate constructions" (2016, p. 4). This will be achieved by the selection of a fairly productive yet understudied construction in present-day Spanish, whose specific discourse functions and further behavior allow for its consideration as a conventionalized independent clause.

The outline of this paper is as follows. Section 2 reviews the literature on insubordination and Section 3 presents the research questions and hypothesis of the study in addition to the data and methodology used to answer and test them. In Section 4, we present 
the findings of the analysis, with discussion of the main discourse-pragmatic functions found for the construction, and a brief preceding revision of some structural properties also associated with it. In Section 5, we summarize the main ideas of the chapter and point to further areas of study.

\section{Background}

The literature on insubordination is not very abundant, especially when compared to that on other long-standing areas of linguistics. However, this domain has been expanding in importance in recent years and research therein has experienced rapid growth since the publication of Evans (2007) seminal paper 'Insubordination and its uses', which served to standardize different previous studies on dependent clauses used independently in various languages of the world-although, in those, the term insubordination was still not used.

Among the works on this area, two very recent book-length treatments of insubordination are worthy of mention-Evans and Watanabe (2016a) and Beijering et al. (2019a). They both gather studies by the most relevant authors in the field, addressing aspects of the phenomenon from different angles and on different languages, complementing each other and providing up-to-date overviews of the current state of research on the phenomenon (Beijering et al. 2019b).

As has been noted in the literature, insubordination represents a challenge for traditional grammatical frameworks because of its ambivalent nature, which combines a subordinate structure with an independent main clause use. The problematic syntactic analysis explains the marginal role given to this type of construction by reference grammars (cf., e.g., for English and Spanish, (Huddleston and Pullum 2002 and Real Academia Española y Asociación de Academias de la Lengua Española 2009), respectively). Insubordination is also a complex phenomenon by virtue of the considerable variation it exhibits in both its structure and discourse functions cross-linguistically (Beijering et al. 2019b).

Among the different typologies that have been proposed, D'Hertefelt and Verstraete (2014) distinguish two types of insubordinate construction, based on a group of Swedish and Danish constructions: (i) expressives, which are used to express the speaker's evaluation of a presupposed state of affairs, and (ii) elaboratives, which elaborate on something that was said before by the same speaker or a different one (D'Hertefelt and Verstraete 2014, p. 90). The ni que insubordinate construction discussed in this study belongs to the first type.

Some scholars mention a cline or continuum of subordination-insubordination (cf., e.g., Beijering et al. 2019b). In this respect, Sansiñena et al. (2015) observe an interesting distinction between what they call dyadically dependent clauses (as in 4) and insubordinate clauses (as in 5):

4. A: ¿Qué dijo?

B: Que te calles.

'A: What did she say? B: That you should shut up'.

5. (Two people are having a strong argument and one says)

¡Que te calles!

'(I insist that you) shut up!' (Literally: 'That you shut up!')

We can compare the two relevant clauses in (4) and (5), in turn, with a third type, their subordinate, dependent counterpart, as in (6).

6. Me dijo: "que te calles".

'She told me: "shut up"'

Whereas the marked clause in (6) can be seen in one of the extremes of the cline, as a fully subordinate, i.e., non-autonomous, clause, (5) is placed at the other extreme, as a fully autonomous, and thus, prototypically insubordinate clause. The dyadically dependent clause in (4), in turn, is seen as a semi-autonomous subordinate clause (Beijering et al. 2019b), thus occupying an in-between position in the subordination-insubordination continuum. Notice that the distinction between (6) and (5) is the same as the one indicated 
above between (1) (Ni que yo fuese Umbral) and (2) (No escribiría una carta cada día ni que yo fuese Umbral). As Beijering et al. (2019b) admit, dyadically dependent clauses are not included by Evans (2007) in his category of insubordinate constructions; however, they are considered as semi-autonomous insubordinates by these authors and illustrate how "dependent clauses used as independent sentences do not represent a uniform, monolithic category" (Beijering et al. 2019b).

One of the ways, and in fact the most important one in our opinion, in which both the dyadically dependent clause, as in (4), and the subordinate counterpart, as in (6), are different from the 'fully' insubordinate, as in (5), we argue, is that only the latter, but not the former two, has an emphatic expressive/emotive meaning. This will be further explored below for the ni que construction.

The discussion of the scale of subordinate-insubordinateness leads us to the hypothesis that the insubordinate construction originates from a process of ellipsis of the main clause, as has often been proposed (notably, e.g., by (Evans 2007)), but also criticized by some authors. Mithun (2008), for instance, finds independent subordinate clauses which do not have this requirement in her data from different indigenous languages. Sansiñena et al. (2015, p. 15) argue that "insubordinate constructions develop along multiple pathways of change, of which the pathway proposed by Evans (2007) is one plausible candidate". Porroche (2000a, 2002, 2003), in turn, considers the subordinator preceding insubordinate clauses not a proper conjunction but a discourse marker that distinguishes itself from a conjunction in various ways.

The range of possible insubordinate constructions appears to be quite restricted (cf. Sansiñena et al. 2015). In a previous study (Alba-Juez and Caro 2017), we looked at the uses and functions of several insubordinate constructions in English and Spanish with different introducing sequences (if only/si (tan) solo, as if/como si, that/que, not that, (pero) si ... ). In the present contribution, we focus on the construction preceded by the sequence $n i$ que in Spanish, which we did not consider previously.

\subsection{Meanings and Functions of Insubordinate Constructions}

Insubordinate constructions are used across languages to perform different discourse functions and it is their adoption of specialized discourse functions that explains their motivation for becoming conventionalized as independent structures (Beijering et al. 2019b).

The literature on insubordination attests a very wide range of functions of these constructions, occurring in different contexts of use. Evans (2007) mentions the three following basic functions: modal meanings, managing the negotiation between speaker and addressee, and discourse organization. Particularly relevant for our purposes, the first meanings, modal meanings, include what he refers to as evaluative insubordination, "in which the omission of the matrix clause implies amazement or shock" (Beijering et al. 2019b, p. 10).

Similarly to Evans (2007), Porroche (2003) finds modal, interactional and textual functions of conjunctions functioning in discourse. Sansiñena et al. (2015) report modal and discourse-connecting uses of insubordinates introduced by que in Spanish.

Mithun (2008), in turn, first called attention to a type of construction in Navajo, the go-marked dependent clause, and similar constructions in other indigenous languages (Yup'ik and Chumash), as dependent clauses used independently. Mithun (2008) analysis differs from that of Evans (2007) in adopting a narrative structure perspective, where the constructions are examined in their wider context, rather than at a local (sentence) domain, and hence, the label 'extension beyond the sentence' adopted by Mithun. The author sees these constructions as exhibiting an off-line discourse contribution to the narrative, providing background information and parenthetical comments, without advancing the story. In addition, these pervasive dependent clauses used independently are also seen to be exploited for several other "social functions", such as relating comments to the general social situation, saving face and showing respect. 
As a conclusion, it can be said that insubordination is "an umbrella term for a formally defined phenomenon which encompasses a wide range of constructions with different formal realizations ( ... ) and whose functions can be mapped cross-linguistically but with different sets of functions for individual languages" (Beijering et al. 2019b, p. 12).

\subsection{Insubordination and the Expression of Emotion}

As stated above, the main argument we support in this work is that one important way in which the ni que dependent construction in Spanish is different from the insubordinate one is that the latter has a stronger emphatic and expressive/emotive meaning. This correlation between insubordinate constructions and affective meanings has been previously noted by some scholars, although only scarcely and without great detail. Authors such as Foolen $(2012$, 2016) or Schnoebelen (2012), for instance, have noticed this in their research about emotion and expressive meanings. Schnoebelen (2012, p. 12) previously mentioned observation that, in some languages, certain dependent clauses are frequently used independently to "mark emotional evaluation and background information" stems from the study by Mithun (2008) mentioned above. In this study, Mithun presents examples from languages such as Athapascan Navajo, in which the particle $=g o$, which normally serves as a subordinate marker, can also appear in utterances where there is no matrix sentence (Mithun 2008, pp. 70-74). Mithun refers to similar phenomena in other languages, such as Yup'ik "autonomous subordinative, the Hualapai 'same' /'different' markers, and the Cree conjunct mode link together series of sentences representing subevents of a larger event or episode, or ideas pertinent to an overarching topic of discussion, rather than to a specific unstated matrix clause". These are all "dependent but not necessarily subordinate in the way that complement clauses might be" (Mithun 2008, p. 107). She presents further evidence from several other studies, such as Iwasaki $(1993,2000)$, where we find a detailed and insightful description of the extension of dependent clause forms used as independent sentences in Japanese. ${ }^{2}$

Our general approach to the study of the expression of emotion entails a discursive perspective within the overall field of functional linguistics, but it also includes an eclectic, multidisciplinary approach enriched by the views and findings of other fields of knowledge, such as psychology, sociology or philosophy. We are conscious of the fact that language is no longer thought to be a totally objective and valid representation of reality; language is viewed in the 21st century as an intersubjective expression of correlational truth, ${ }^{3}$ where the expression of emotion plays a fundamental part (Lüdtke 2015). We now know that emotion permeates all linguistic levels (Schnoebelen 2012; Majid 2012; Foolen 2016; AlbaJuez and Mackenzie 2016, 2019) and that it can manifest itself in different forms and modes. The focus of this study is its manifestation at the syntactic level by the use of the ni que insubordinate construction, as a particular form-meaning pairing, such as shown in the previous examples and in (7):

7. ¡Y ustedes, cuidadito con ir con cuentos a los Montero, ni a esas barrigas resfriadas de las Bringas! —nos previno madre a Laura y a mí.-Ni que fuéramos unas chusmas.

'And you; be careful with going to the Monteros or to the blabbermouthy Bringas, with invented stories. As if we were gossipy women!'

\section{(CdE 126. Novios de Antaño, María Elena Walsh)}

However, it is important to note here that, even if the syntactic level is the one taking the lead in this particular linguistic manifestation of emotion, the pragmatic level intertwines with it as well as with all the other levels. ${ }^{4}$

We want to clarify here that we will use the terms expressive and emotive indistinctly to refer to the emotional content of utterances and discourse in general, not without being aware of the fact that different terms are used by different authors to refer to the phenomenon of human emotion. Batson et al. (1992, p. 295), for instance, state that in psychology, the terms affect, mood and emotion are most often used interchangeably, but 
other authors do not treat them in an equal manner. Tomkins (1982, p. 354), in turn, distinguishes between affect, feeling, mood and emotion: affect is defined as the primary motivational system, feeling as the conscious awareness of an affect, mood as a persistent state of emotion, and emotion as a combination of an affect, a feeling and memory of previous experiences of the initiating affect. Cognitive linguists such as Schwarz-Friesel (2015, p. 161) define emotion as "a complex internally represented knowledge system having a primarily evaluative function within the human organism". Within Systemic Functional Linguistics (cf. Martin and White (2005) Appraisal Theory), the predominant term used is Affect, which constitutes one of the subsystems of Attitude, and is "concerned with registering positive and negative feelings" (2005, p. 42). We could provide a much more extensive discussion related to the terminology used, but by doing so, we would exceed the scope of this paper. For the purposes of the analysis made herein, we will take as our point of departure Alba-Juez and Mackenzie's $(2019$, p. 18) definition of emotion in discourse:

[... ] we view emotion as a (dynamical) system of language which interacts with the system of evaluation but whose main function is the expression of the speaker's feelings, mood or affective experience. It is a multimodal discourse process, ${ }^{5}$ which permeates all linguistic levels but also manifests itself in nonverbal ways, ${ }^{6}$ presenting different stages and forms (influenced by variables such as pragmatic expectations or common-ground knowledge) according as the discursive situation and interaction changes and evolves.

This definition considers the different parameters and variables that point towards the presence of emotion in discourse, such as the linguistic level at which it is manifested (by means of, for instance, lexicon, morphemes, constructions or inferences), or the mode of the emotion (e.g., linguistic, paralinguistic or by means of emoticons in the case of computer-mediated discourse). For a more extensive description of these variables, see Alba-Juez (2016, 2018).

In analyzing the ni que constructions in the corpus, we will focus on the different pragmatic domains and functions of this construction, including the role of ni que as a discourse marker, which has the power of expressing and manifesting dynamical intersubjective affective meanings. We are aware of the inconsistency in the literature in the use of the terms pragmatic marker and discourse marker. In this work, we choose the label discourse marker in the sense of Schiffrin (1987) as a wide, all-embracing category, including markers whose main function is the connective one (cf. (Fraser 2006) here, and his distinction between pragmatic markers and discourse markers, the latter as a sub-category of the former, and whose main function is the connective one).

\section{Research Goals and Methodology}

\subsection{Research Questions and Hypothesis}

The study presented herein arose from our interest in testing Schnoebelen (2012) assertion about the possibility for some dependent clauses to act independently in order to mark emotional evaluation. In particular, we wanted to know if this would be the case for the insubordinate construction initiated by ni que in Spanish. Our main research questions are, therefore, the following:

(a) Is the sequence ni que (when introducing an insubordinate construction) used as a discourse marker fulfilling an emotive/expressive function in Spanish?

(b) Are the insubordinate ni que clauses in Spanish different from their subordinate equivalents as far as their emotive content is concerned?

(c) Are there any other important domains (textual, interpersonal or modal) and functions that the ni que construction forms part of and fulfills?

As can be seen, we herein adopt the term domain, taken from Crible and Degand (2019) to refer to "macro-functions which roughly correspond to the speaker's intention and degree of involvement" (Crible and Degand 2019, p. 4). Domains are thus understood as clusters 
of functions which, as a general category, can integrate more specific discourse functions but which are considered independent from the latter (Crible and Degand 2019, p. 4).

Based on these initial questions, our derived hypothesis was the following: One of the features that characterizes the insubordinate constructions initiated by ni que in Spanish is their emphatic and expressive function (found within the interpersonal domain). As we said above, this distinguishes them from their subordinate counterparts, whose function is not emphatic or affect-centered. Compare the sentences in (8).

8. a. Subordinate ni que clause:

No me aprovecharía de ti ni que me tuvieras miedo.

Apodosis Protasis

'I would never take advantage of you; not even if you were afraid of me,'

b. Insubordinate construction (Protasis without apodosis):

Acércate. Dame la mano. Dámela, hombre. ¡Ni que me tuvieras miedo!

'Come near. Give me your hand. Give it to me, for goodness sake. As if you were afraid of me!'

(CdE 86. Gran Señor y Rajadiablos, Eduardo Barrios)

One noticeable difference between the dependent concessive clause and its insubordinate counterpart is that the ni que in the former can be replaced by ni aunque without altering the meaning (cf. Gras 2007, p. 311). Furthermore, insubordinate constructions with ni aunque can generally be recovered without changing its meaning, as shown in (9):

9. A: Pues mire usted que me he hecho viejo en el oficio ... y, por último, de usted es la novilla y mío el dinero; la feria es tanto para pedir como para ofrecer, sin ofensa de nadie ni menosprecio de la cosa. Otro dará más.

'You should know that I have become old and experienced in the trade ... and lastly, the heifer is yours and mine is the money; the fair is both for asking and bidding, without offending anybody or underestimating the matter. Some other person will give you more'.

$\mathrm{B}:$ ¡Ni aunque me la pesaran en oro!

'Not even if they weighed it in gold!'

A: Y hará usted bien, si en tanto la estima

'And you will thus do well if you so much appreciate it'

(CdE 25. Don Gonzalo González de la Gonzalera, José María de Pereda)

Here, both the dependent clause in No vendería la novilla ni aunque me la pesaran en oro and the semi-autonomous insubordinate counterpart found in the example would be equivalent, and for this reason, the apodosis can be recovered without altering the expressive meaning of B's statement. However, if we tried to make this replacement in insubordinate constructions such as the one in (8b), the meaning would change considerably, because, in fact, ${ }_{i} \mathrm{Ni}$ aunque me tuvieras miedo! could not be considered as an appropriate equivalent option in that particular context. This suggests that the concessive meaning attached to the subordinate construction is somehow lost or not found in the insubordinate one, whose meaning has more to do with pragmatic phenomena such as the triggering of counterfactive presuppositions, the organization of discourse, the emotive domain and the realization of expressive speech acts, as we shall further illustrate and discuss in Sections 4.2-4.4.

\subsection{Corpus}

Our corpus consisted of more than 2000 concordances and their extended contexts from two corpora of the Spanish language, namely:

(a) The Davies' Corpus del Español (CdE), where we examined 1067 concordances in both Peninsular and American varieties of Spanish and found 128 insubordinate constructions (representing 12\% of the scrutinized ni que concordances in it); 
(b) The CORPES XXI, where we examined 1001 concordances in Peninsular Spanish and found 104 insubordinate constructions (representing then $10.39 \%$ of the ni que concordances).

It is worth noting that the ni que insubordinates were mostly found in the spoken language section of the corpora used and in the dialogue sections of written language or written fiction works, in the form of direct reported speech or thought, more or less explicitly indicated in the text. So, even when it is found in written texts, it is always representing the oral use of the construction, which leads to the assumption that the $n i$ que discourse marker in insubordinate constructions is mainly a feature of spoken Spanish. This undoubtedly has to do with the illocutionary force accompanying them, which very frequently is that of a direct or indirect retort (cf. Porroche 2000b).

\section{Analysis and Discussion}

In the insubordinate construction, the otherwise conjunction $n i$ has an independent value which does not allow for conjunctive locutions (Real Academia Española y Asociación de Academias de la Lengua Española 2009, p. 2461). We have observed that the ni que insubordinates are normally triggered by the previous linguistic or extralinguistic context, which is not surprising, considering that, as the data examined show, the ni que sequence acts as a discourse marker within the expressive/emotive domain, and as such, any contextual cue in its interpretation is crucial (cf. Crible and Degand 2019). Consider this fact in (10), where both the linguistic and extralinguistic contexts make for the whole meaning of ni que as an interpersonal emotive marker. The speaker responds here to the facial expression of surprise/astonishment of her interlocutor:

10. Oiga, ¿qué le pasa? Ni que le hubiera contado una historia de fantasmas... ¿no es Ud. periodista? Seguro que ha oído casos más raros que éste o ¿está creyendo que estoy loca?

'Listen, what's the matter with you? As if I had told you a ghost story ... Aren't you a journalist? Surely you've heard of stranger cases than this one, or do you believe I'm crazy?'

\section{(CdE 146. Desenlaces, Lucía Melgar)}

As stated above, this construction operates on different linguistic and discourse-pragmatic levels, some aspects of which we shall discuss in the next subsections (Sections 4.1-4.4). One interesting pragmatic aspect found is the fact that the ni que insubordinate clauses normally trigger a counterfactive presupposition, which works as the linguistic support for its interpretation as emotionally loaded markers. We turn to this in Section 4.2, but first, in Section 4.1, some structural features of the construction in Spanish are presented.

\subsection{Defining the ni que Insubordinate Construction in Spanish from a Formal Perspective}

In this subsection, we look at the distinction between the ni que insubordinate construction and other superficially similar dependent sentences used independently, introduced by the sequence ni que in Spanish but whose function is different; thus, they have to be considered different constructions. The following discussion focuses on sentences where the ni que sequence is followed by a tensed verb, leaving apart other, often highly conventionalized constructions with a non-finite verb (i.e., an infinitive), such as, e.g., Ni que decir tiene que ... 'it goes without saying that ... '. By discriminating between the ni que insubordinate and other superficially similar constructions, we hope to offer an overview of the main formal features associated with the former, without pretending to give a detailed and complete account of these, which goes beyond the scope of the present study.

Similar dependent sentences used independently introduced by ni que in Spanish can be coordinated or subordinated; as mentioned above, neither of these has been included in our dataset as their function is different from that of the insubordinate ni que construction under study. The former group can be illustrated by (11), where ni ('neither/nor') is a negative coordinator. 
11. Cállese. Yo no quiero ser amigo suyo. Ni que nos tuteemos.

'Shut up. I don't want to be a friend of yours. Nor that we address each other using the familiar'.

(CORPES 38. La aventura del tocador de señoras, Eduardo Mendoza)

Using the term 'semi-autonomous' subordinate (or insubordinate) construction from Beijering et al. (2019b), the construction in (11) can be characterized as a 'semi-autonomous coordinate' construction. A paraphrase of (11), for example, is Ni quiero que nos tuteemos 'Nor do I want that we address each other using the familiar'.7 By contrast to this construction, the word $n i$ in the insubordinate is not a coordinator but a scalar adverbial particle or negative operator (cf., e.g., (Gras 2007, p. 312; Yates 2006)). This will be further explained below.

In (12), in contrast with (11), ni que introduces a subordinate clause, presented as independent, but also different from the ni que insubordinate construction that we are concerned with.

12. No le dé dulces, Bendición. Ni que llore.

'Don't give her sweets, Bendición. Even if she cries'.

(CORPES 506. Princesas, Fernando León de Aranoa)

The italicized construction in (12) is a 'semi-autonomous subordinate' clause with a concessive-conditional meaning, in which the sequence ni que can be paraphrased by ni aunque (cf. (No le dé dulces), ni aunque llore), as noted above and in Gras (2007). A common feature of the ni que semi-autonomous subordinate and the ni que insubordinate construction is the presence, in both cases, of the $n i$ as a scalar negative operator.

Since $n i$ is analyzed as a scalar (negative) operator (cf., e.g., Gras 2007), a word is in order based on the concept of scalarity. From a pragmatic point of view, scalarity involves the existence of a set of potential propositions related to an event from a scale of values present in the discursive frame of the speech participants, and from which the speaker selects one as the most relevant given the circumstances (cf. also, among others, (Ducrot, 1980; Fauconnier 1975; Kay 1990; Yates 2006)). We may use our previous example (1), (jUna carta cada día!) ¡Ni que yo fuese Umbral!, to illustrate this. Writing a letter everyday (to a physically distant girlfriend) presupposes a set of potential possibilities that can explain this proposition: for example, to find writing attractive, to be a good writer or to write for a living (i.e., to be a writer). Among these, the scalar operator $n i$ selects one seen as highly remote and improbable in that scale, and whose selection implies all the other set of possibilities. Thus, negating that possibility implies negating all the others below it. In (1), the selected option is 'being one of the most prolific contemporary writers of 20th century Spain', in this case, referring to the novelist and journalist (Francisco) Umbral. The selection of that highly remote possibility has the effect of emphatically negating the previous related statement (writing a letter every day).

Precisely, in our analysis, we have also noticed that the scalar nature of $n i$ is a crucial factor for the emotive interpretation of the insubordinate construction with ni que. As noted in cognitive linguistics (see Kay 1990), a scalar model consists of a set of interrelated propositions, which generally belong to a discourse frame that is shared by the interlocutors. So, for instance, ¡Ni que yo fuese Umbral! is presented as the utterance with a greater degree of informativity for being the most negative one as compared with other propositions of the same set. The contrast shown by presenting the most negative option as a non-accepted hypothetical possibility includes an emphatic emotional component of indignation that is certainly triggered by the presence of the pragmatic content of the scalar operator $n i$.

A fundamental point in the analysis of this insubordinate construction has to do with the character of the sequence ni que. Rather than a combination of two conjunctions, we consider it as a sequential discourse marker, where the scalar operator $n i$ has grammaticalized with que into one conjunction. Our thesis is that ni que functions as a discourse marker performing the role of an initiator of main clauses. This is in line with the work of authors 
such as Porroche for Spanish (cf. Porroche 2015) or Detges (2017) on puisque in French, and will be further expanded in Section 4.3.

As may have become evident from the examples presented in the previous sections, one of the characterizing features of the insubordinate construction in Spanish with $n i$ que is the subjunctive verbal form following ni que. The subjunctive is found in other insubordinates in Spanish introduced by other sequences (Como si eso fuera a arreglar algo 'As if that were to solve anything'; ; Que te calles! '(I insist you) shut up!') but by no means in all of them; thus, the present indicative (Que te quiero, joder, que te quiero 'That I love you, damn it, that I love you') or the future ( $j$ Si seré despistada! 'How absent-minded I am!') are used as well. However, with the ni que insubordinate construction, the subjunctive is a requirement. The required subjunctive is seen as a reflection of the non-factuality of the state of affairs depicted and the unreality of the presented proposition. ${ }^{8}$ Thus, compare the 'semi-autonomous coordinate' in (13a), containing the indicative hace 'it-has been', with its insubordinate counterpart in (13b), with the subjunctive form hiciera.

13a. Porque no puedo olvidar, porque no puedo ignorar, que al fin he conseguido arruinarme. Ni que hace más de dos años que perdí a mi mujer.

'Because I cannot forget, because I cannot ignore, that finally I ended up bankrupt. Nor that it has been more than two years since I lost my wife'.

(CORPES 227. Grillo, José Machado)

13b. ¡Ni que hiciera más de dos años que perdí a mi mujer!

'As if it had been more than two years since I lost my wife!'

Whereas the indicative in (13a) indicates a factual state of affairs ('it has indeed been more than two years that I lost my wife'), the subjunctive in (13b) expresses non-factuality, the implication being that the speaker's wife passed away less than two years before the moment of speaking, that is, it is not the case that she died more than two years since then.

A highly conventionalized construction is the clause ni que lo digas, as in (14).

14. -Está buena, la Elisa esa ... -dice Gabriel.

'-She's hot, that chick Elisa ... -says Gabriel'.

-Ni que lo digas -dice Toni.

'-Oh yes/Absolutely -says Toni'.

(CORPES 967. El hijo del futbolista, Coradino Vega)

As can be seen in (14), the fixed expression ni que lo digas is used in Spanish for expressing strong agreement. This is a semi-autonomous subordinate clause that can be paraphrased in Spanish as es tan evidente que no hace falta ni que lo digas ('it is so obvious that you need not even say it'), stressing the self-evident or non-dubious character of the previously mentioned statement.

In Section 2, we mentioned the proposed view of the insubordinate construction to have emerged from a process of ellipsis of the main clause (Evans 2007). In some cases, but by no means always, the main clause can be easily retrieved and the reasons for the speakers to have abandoned that clause seem clear. One of the most obvious contrasts between the ni que insubordinate construction and other insubordinate constructions in Spanish is that in the former, the main clause (apodosis) is not retrievable from the context, without a change in meaning. Thus, compare (15) and (16) with (17).

15. iQue te calles! $\rightarrow$ He dicho que te calles. 'I have said that you should shut up'.

16. ¡Si tan solo pudiera verte! -> Si tan solo pudiera verte, me quedaría más tranquila. 'If only I could see you, I would be less anxious'.

17. ¡Ni que yo fuese Umbral! -> \#No te escribiría una carta todos los días, ni que yo fuese Umbral. 'I would not write to you a letter everyday, even if I were Umbral' 
Whereas the insubordinates in (15) and (16) can become subordinates attached to a main clause, retaining their meaning, the emotive/expressive meaning of the ni que insubordinate in (17) is lost when attaching it to the retrieved apodosis from the preceding context (see (1-2) above). Therefore, the meaning of the ni que insubordinate changes substantially when converted into a subordinate, whose meaning as said above is concessive-conditional. We argue that this different behavior of the ni que insubordinate is a reflection of the conventionalization of this construction in Spanish. Thus, the development of specific discourse functions and, in particular, the systematic association of the emotive/expressive meaning with the ni que insubordinate clause over time, by contrast to other similar constructions, suggest the conventionalization analysis. Furthermore, from the impossibility of retrieving the apodosis in this case, it follows that the ni que insubordinate construction does not have a dyadically dependent equivalent, as mentioned by Sansiñena et al. (2015), in contrast with other insubordinates such as for que te calles (cf. [(4) above).

Another aspect worth considering has to do with intonation. Parenthetical ni que subordinate clauses, in addition to triggering an inversion in the polarity of the main proposition (due to its properties as a negative word), receive an intonation that is associated with dislocated elements (Gras 2007, p. 314). In the case of the insubordinate ni que clause, we have observed that, as is the case with other expressive constructions, the falling intonation as well as other prosodic features typically associated with it, such as the use of a higher pitch in the ni que clause with respect to the surrounding discourse, contribute to its interpretation as a marker of emotion.

The expressive meaning of the ni que insubordinate construction is often reinforced by the use of discourse markers and vocatives in the same clause or in the immediate environment where insubordinate clauses occur. Thus elements such as hombre (as in (8b) above), chica (as in ;Ni que fuera Navidad, chica!, 'As if it were Christmas, girl!' (CORPES 973)), hija, oye, vamos, and others recur in our examples. As noted by Domínguez (forthcoming), these accompanying elements may be seen as an alterity marker showing some kind of disagreement, or even anger.

\subsection{Ni que Insubordinate Clauses as Triggers for Counterfactive Presuppositions}

As noticed above, the ni que insubordinate construction always contains a subjunctive form of the verb, which reflects the non-factuality of what is described in the ni que clause. This is in agreement with the pragmatic emotive content observed in the corpus, as the construction normally acts as the linguistic trigger for a counterfactive presupposition ${ }^{9}$ that is frequently related in some way or another to a negatively loaded emotion (e.g., fear, contempt, anger, disappointment). Consider (18):

18. Acércate. Dame la mano. Dámela, hombre. ¡Ni que me tuvieras miedo!

'Come near me. Give me your hand. Give it to me, for goodness sake. As if you were afraid of me!'

\section{(CdE 86. Gran Señor y Rajadiablos, Eduardo Barrios)}

In this particular example, the triggered counterfactive presupposition would be "(Sé que) no me tienes miedo" ((I know that) you're not afraid of me), and it involves the negative emotion of fear in an inscribed manner (Martin and White 2005), ${ }^{10}$ but at the same time, the speaker wants to come across as precisely the opposite, as someone whom the interlocutor should trust and not fear, thereby invoking a more reassuring and positive emotion.

19. Ni hablar. Una camisa de manga larga ¿para qué? Ni que fueras de boda, hijo mío. Esta camisa luego no te la vuelves a poner en la vida.

'Absolutely not. A long-sleeved shirt? What for? As if you were going to a wedding ceremony, my son. This shirt then you'll never wear again in your life'.

(CORPES 182. Los aires difíciles, Almudena Grandes) 
The counterfactive presupposition triggered by the ni que clause in (19) is that the addressee is not going to a wedding ceremony, and from there, the negative attitude of the speaker, who does not want to buy her son a long-sleeved shirt, thereby implying that her son's idea is out of the question and inappropriate.

Gras (2007, p. 317) remarks that the scalar operator $n i$ in Spanish often gives place to the working out of conventional implicatures. As a matter of fact, conventional implicatures have very much in common with presuppositions, because they are both inferences grounded in concrete linguistic elements. Actually, linguists have not yet come to an agreement as to what the difference (if any) between one and the other might be, and this is the reason why many authors, such as Karttunen and Peters $(1975,1979)$ or Grundy $(2008)$ treat them as if they were the same phenomenon.

\subsection{Ni que as a Discourse Marker Affecting Textual-Organizational Domains}

As anticipated in Sections 1 and 2, we herein claim that the sequence ni que in Spanish, when used in insubordinate constructions, acts as a discourse marker.

Porroche $(2000 \mathrm{~b})$ is one of the very few authors that has explored the discourse values of $n i$ in Spanish, and she presents examples of the insubordinate construction with ni que as instances of the fact that it can function as a discourse marker/operator, by virtue of the fact that these markers acquire a conventional function and a conversational meaning according to the context and verbal interaction in which they are found.

As is well known, one of the defining features of discourse markers is that they are multifunctional, and this is a feature that we have observed in the ni que discourse marker in Spanish as well. Crible and Degand (2019), for instance, remark that any domain or macrofunction can combine with any microfunction at the utterance level. In the same vein, Domínguez (forthcoming) has found that certain discourse markers in Spanish can combine both an emotive and a metadiscursive macrofunction related with the organization of dialogical dynamics, and it is in this light that we shall look into the ni que insubordinate constructions. In line with Dominguez's findings, we have noticed that the $n i$ que insubordinate construction often fulfils a textual function related with the organization of discourse (e.g., topic closure) or with some interpersonal matter (e.g., breaking the silence), which, at the same time, is tainted with an expressive content of some sort at both the wider textual/discourse level and the utterance level of the speech act. Example (18) above ( ... ¡Ni que me tuvieras miedo!) illustrates how this construction is used to break the silence and/or inaction of the interlocutor, as a discourse smoothening function showing the workings of an emotive system expressing mixed emotions (inscribed fear vs. invoked confidence). Examples (20) and (21) also illustrate this coalescence of domains and functions:

20. —Quédate a vivir conmigo- $[\ldots]$

'Stay in my house and live with $\mathrm{me}^{\prime}$

— iNi que estuviera loca! -dijo ella y se dio la media vuelta.

'As if I were mad! -she said, and she turned around (and left)'.

(CdE 151. El Rompecabezas, Ricardo Martínez Cantú)

21. —iVaya tontería! ¿Quién iba a descubrirlo? Además, ni que hubiera algo malo en ello.

'How foolish! Who would discover it? Besides, as if there were something wrong in it'.

(CORPES 229. Sabatina, José Luis Borau)

The insubordinate construction in (20) is used organizationally as a topic closure mechanism, which, at the same time, shows the contempt and annoyance of the speaker towards the suggestion that s/he might speak in a certain manner. In the case of (21), the organizational function has to do with the continuity of the topic, including an additional argument to the previous ones exposed, all of which fulfil the coalescing function of 
expressing certain surprise and contempt as a retort for some foolish idea previously expressed by the interlocutor.

It is worth noting here that these insubordinate constructions always help move the discourse forward, since they are normally used to react to some previous statement or situation that calls for a more or less emotive reaction. This is the reason, we believe, why we have found many instances in which they fulfil the topic closure or topic continuator function, but no instances of them being used as topic initiators.

\subsection{Ni que as a Marker of Expressive Illocutionary Acts}

At the same time as serving different organizational discourse functions, the ni que insubordinate construction is marked by some kind of emotive/expressive illocutionary force. As such, it may fulfil several (normally expressive) functions at the utterance microlevel of the illocutionary act, such as reproach, complaint, rebuttal, counter-argumentation or negative criticism, among others. In all the examples examined, the ni que insubordinate construction comes across as a retort, which somehow questions a previous remark or action on the part of the interlocutor or a third party. Consider (22):

22. No fue capaz de ayudar con los bolsos. ¡Ni que fuera una dama inglesa!

'She wasn't even capable of helping with the bags. As if she were an English Lady!'

\section{(CdE 93. Tántalo en el Trópico, Nila López)}

We can place this instance of insubordinate ni que construction within the emotive domain, as the speaker is expressing her disdain and anger for what she judges as an inappropriate attitude on behalf of the woman she is criticizing, which, at the microlevel of the illocution, translates into an expressive and emphatic act of complaint.

Very frequently these insubordinate constructions present a humorous or ironic (unreal or ridiculous) hypothetical situation. Humor always appeals to the interlocutors' emotions, as illustrated in (23) and (24):

23.- ¿Y no pudiste, dímelo con franqueza, reconocer a tu agresor?

'And couldn't you, tell me in all frankness, recognize your aggressor?'

- Imposible. Ni que yo tuviera como los gatos el privilegio de ver en la oscuridad.

'Impossible. As if I had, like cats, the privilege of seeing in darkness'.

(CdE 241. El Sochantre de mi Pueblo, Ginés Alberola)

24. ¿De dónde vamos a sacar la plata para eso? [ ... ] Tengo que ser sincero que desde el principio no vamos a poder hacer todas las obras (... ) Ni que fuéramos Mandrake el Mago combinado con Supermán.

'Where are we going to take the money for that from? [ ... ] I have to be sincere with you that at the beginning we won't be able to do all the works ( ... ) As if we were Mandrake the Magician combined with Superman'.

(CdE 176. Prensa libre, CR:PrLibre:98May16)

As noted above, the ni que insubordinate constructions normally present a counterargument, criticism or lack of agreement with the interlocutor or some third party. Therefore, it is not uncommon for speakers to resort to humor as a pragmatic resource, which acts as a catalyst for the negative feelings, balancing them with positive emotion and the ability to elicit laughter in the hearer. The humor used normally contains hyperbolic, absurd or impossible scenarios that contrast with the real situation being discussed, as shown in (23), by triggering the counterfactive presupposition that "(It is obvious that) I don't have the ability, like cats, of seeing in darkness" or in (24), similarly implying that "they are not Mandrake the Magician or Superman".

Now, by way of a model example incorporating the other pragmatic aspects discussed in Sections 4.2 and 4.3, we could complement our analysis of (24) by summarizing it in the following three points $(\mathrm{a}, \mathrm{b}$ and $\mathrm{c})$ : 
(a) Pragmatic meanings. Counterfactive presupposition: (Sabemos que) No somos ni Mandrake el Mago ni Supermán '(We know that) We are neither Mandrake the Magician nor Superman'.

(b) Discourse-emphatic/humorous-emotive domain: Presenting a humorous (unreal or ridiculous) hypothetical situation. The humor also fulfills an emphatic but, at the same time, mitigating macrofunction. The speaker here wants to save face (Brown and Levinson 1987) by minimizing the possible aggressiveness of the counterargument or criticism implied, thereby appealing to the interlocutors' positive face and emotions.

(c) Microfunction (speech act level): Self-justifying, expressive illocutionary act, also showing the speaker's reprobation of the previous (apparently absurd or unreal) assumption on the part of the interlocutor that they will have the money to do all the works now.

\section{Conclusions}

Our main aim when embarking on this study has been to explore the emphatic and expressive potential of the ni que insubordinate construction in Spanish, as contrasted with its subordinate counterpart. So, the main argument defended here has been that one important way in which the ni que dependent construction in Spanish is different from the insubordinate one is that the latter has a stronger emphatic and expressive/emotive meaning. In this respect, the results of our corpus analysis have led us to the following conclusions.

The ni que insubordinate construction can perform different discourse functions, and an important factor that makes it different from its subordinate counterpart is precisely the adoption of the specialized emotive function that explains its conventionalization as an independent construction.

Even though emotion permeates all linguistic levels, in the particular case of the $n i$ que insubordinate construction, the emotion is mainly manifested at the syntactic and the pragmatic levels, the ni que construction obviously being a syntactic phenomenon whose interpretation and comprehension necessarily needs to be based on the (socio)pragmatic context and information surrounding the genre (normally spoken language in conversation or representations of spoken language in writing) and the speech act in which it occurs. Indeed, the scalar nature of this syntactic construction is precisely one of the crucial factors for its emotive interpretation.

Syntactically, the ni que insubordinate construction always contains a subjunctive form of the verb, which reflects the non-factuality of what is described in the ni que clause. This is in agreement with the pragmatic emotive content observed in the corpus, as the construction normally acts as the linguistic trigger for a counterfactive presupposition that is frequently related in some way or another to a more or less negatively loaded emotion.

The ni que sequence then presents particularities regarding different domains and functions, including its roles as a discourse marker expressing and manifesting dynamical intersubjective affective meanings. It often fulfils a textual function related with the organization of discourse (e.g., topic closure) that is, at the same time, tainted with an expressive content of some sort.

A noticeable difference between the insubordinate and the subordinate constructions with ni que lies in the fact that the concessive meaning normally attached to the latter is lost or not found in the former, whose conventionalized meaning has more to do with pragmatic phenomena such as the triggering of counterfactive presuppositions, the organization of discourse, the emotive domain and the realization of expressive speech acts.

The illocutionary force normally accompanying the $n i$ que insubordinate construction is that of a direct or an indirect retort, which can also take the shape of other (very frequently) negatively polarized acts such as complaints, criticisms or counterarguments.

These constructions frequently contain an element of irony or humor as a pragmatic resource that acts as a catalyst for the possible negative feelings, balancing them with positive emotion and the ability to elicit laughter in the hearer. 
We believe that all of these features have contributed to the conventionalization of the insubordinate ni que clauses as independent constructions that lie apart in meaning from the concessive subordinate ni que counterparts in Spanish. This makes the insubordinate constructions worth studying on their own for their characteristic way of conveying emotional meanings. As has been shown, two outstanding ways in which this construction conveys emotional meanings are: (a) through the working out of counterfactive presuppositions, and (b) through its capacity to function as a discourse marker.

By focusing on the expressive function of the ni que insubordinate construction in Spanish, it is obvious that we have not been able to offer a complete account of the construction. One further issue worth studying, for instance, would be the exact distinction between this construction and the similar Spanish insubordinate introduced by como si as in ;Como si yo pudiera mandar aquí!, 'As if I could rule in here!', which shares with the ni que insubordinate the denial of the main proposition (i.e., "Yo no mando aquí"-Compare with ;Ni que yo pudiera mandar aqui!). A related issue is that a contrastive study between the ni que insubordinate and its equivalents in other languages could also add to define its precise semantic/pragmatic meaning and use in discourse. Thus, as can be seen in our own translation of the Spanish examples presented, the best alternative in English for the construction is one introduced by as if.

Another interesting avenue of research would be to look into the wider contexts in which the ni que insubordinate construction appears in the larger stretches of discourse where it occurs. Such a discourse analysis would reflect the role of the construction "link[ing] together series of utterances representing subevents of a larger episode, or ideas pertinent to an overarching topic of discussion" (Mithun 2008, p. 107). Thus, the meanings found by Mithun (2008) for her indigenous languages as exhibiting off-line discourse contributions to the narrative structure could be tested for the ni que insubordinate in Spanish.

Author Contributions: Both authors have had equal participation in this study. Both authors have read and agreed to the published version of the manuscript.

Funding: This research received no external funding.

Institutional Review Board Statement: Not applicable.

Informed Consent Statement: Not applicable.

Data Availability Statement: The data can be found in the corpora used for the analysis.

Acknowledgments: The authors would like to thank the guest editor of this special issue, Renata Enghels, and the three anonymous reviewers for their insightful and useful comments to an earlier draft of this paper.

Conflicts of Interest: The authors declare no conflict of interest.

\section{Notes}

1 At the end of the examples, the source is indicated in brackets with the following information: name of the corpus, number of the example in our dataset, name of the text and author. (See Section 3.2 for further information on the corpora.) The sequence ni que is marked in bold in all examples.

2 Iwasaki (2000, p. 237) reports that in Japanese of the Heian period (circa ninth through twelfth centuries), verbs and auxiliaries in declarative sentences were inflected either as finite forms with -keri or as attributive forms with -keru. These were used both in relative and main clauses, the latter use performing three distinct functions: (i) background information, (ii) exclamation, and (iii) weak conjecture.

3 However, this idea had started developing at the end of the 20th century, within the development of the framework of cognitive linguistics, for instance.

$4 \quad$ Gras (2007, pp. 311-12) also sees this overlap of levels for the ni que construction when he states that the presence of ni que is a syntactic phenomenon because it determines the grammatical relation between the main proposition and the subordinate one, but it is also necessary to resort to pragmatic information to account for the functioning of the connective sequence ni que composed by the negative scalar operator $n i$ and the conjunction que. 
5 Multimodality is taken into account in this study to the extent that the information and extended contexts provided for the examples in the corpora used allow us to, but in general, we will be working with written language and written representations of spoken language.

6 We refer here to non-verbal manifestations of emotion such as bodily movements or face gestures, which for this study, we have taken into consideration inasmuch as the information in the corpus has allowed us to.

7 Of course, these constructions may occur as 'normal' coordinated clauses within a compound sentence, rather than independently: No quiero ser amigo suyo ni que nos tuteemos.

8 As Gras (2007, pp. 312-13) notes, the subjunctive is also a requirement in the ni que subordinate counterpart, for the same semantic-pragmatic reasons mentioned for the insubordinate.

9 Counterfactive presuppositions are normally associated with counterfactive verbs such as wish or pretend in English (e.g., in I wish I were there, the presupposition triggered is that I am not there), which make the hearer infer that the action or situation expressed is not true or did not happen at all. In the case of the insubordinate construction being discussed here, it is not a verb but the $n i$ que sequence that acts as the counterfactive element, given the negative scalar value assigned to it (see Section 4.1 above).

10 Martin and White define inscribed evaluation (including Affect as one of its subsystems) as an evaluation that is directly expressed through language, not implied. A simple example would be "She was angry".

\section{References}

Alba-Juez, Laura. 2016. The variables of the evaluative functional relationship: The case of humorous discourse. In Metapragmatics of Humor: Current Research Trends. IVITRA Research in Linguistics and Literature. Edited by Ruiz Gurillo Leonor. Amsterdam: John Benjamins, pp. 11-34, ISBN 978-90-272-4020-0 (HB); ISBN 978-90-272-6637-8 (e-book). [CrossRef]

Alba-Juez, Laura. 2018. Emotion and appraisal processes in language: How are they related? In The Construction of Discourse as Verbal Interaction. Edited by María de los Ángeles Gómez González and John Lachlan Mackenzie. Amsterdam: John Benjamins, pp. 227-50. [CrossRef]

Alba-Juez, Laura, and Elena Martínez Caro. 2017. Estudio comparativo de la 'insubordinación' en inglés y en español, con especial énfasis en su función expresiva. In XLVI Simposio Internacional de la Sociedad Española de Lingüística. Madrid: CSIC, January.

Alba-Juez, Laura, and John Lachlan Mackenzie. 2016. Pragmatics: Cognition, Context and Culture. Madrid: McGraw Hill.

Alba-Juez, Laura, and John Lachlan Mackenzie. 2019. Emotion processes in discourse. In Emotion in Discourse. Edited by J. L. Mackenzie and L. Alba-Juez. Amsterdam: John Benjamins, pp. 3-26.

Batson, C. Daniel, Laura L. Shaw, and Kathryn C. Oleson. 1992. Differentiating Affect, Mood, and Emotion: Toward Functionally-Based Conceptual Distinctions. Review of Personality and Social Psychology 13: 294-326.

Baumgarten, Nicole, Inke Du Bois, and Juliane House, eds. 2012. Subjectivity in Language and Discourse. Leiden: Brill.

Beijering, Karin, Gunther Kaltenböch, and María Sol Sansiñena, eds. 2019a. Insubordination. Theoretical and Empirical Issues. Berlin: Mouton de Gruyter.

Beijering, Karin, Gunther Kaltenböck, and María Sol Sansiñena. 2019b. Insubordination: Central Issues and Open Questions. Berlin: Mouton De Gruyter, pp. 1-21.

Biber, Douglas, Stig Johansson, Geoffrey Leech, Susan Conrad, and Edward Finegan. 1999. Longman Grammar of Spoken and Written English. London: Longman.

Brown, Penelope, and Stephen Levinson. 1987. Politeness: Some Universals in Language Usage. Cambridge: Cambridge University Press.

Crible, Ludivine, and Liesbeth Degand. 2019. Domains and functions: A two-dimensional account of discourse markers. Discours 24: 3-35. [CrossRef]

Detges, Ulrich. 2017. Insubordinated puisque in French. Grammaticalization, De-Grammaticalization, Reanalysis? JournaLIPP 5: 17-32.

D'Hertefelt, Sarah, and Jean-Christophe Verstraete. 2014. Independent complement constructions in Swedish and Danish: Insubordination or dependency shift? Journal of Pragmatics 60: 89-102. [CrossRef]

Domínguez, Noemí. (forthcoming). Marcadores del discurso en contextos de emoción. In Estudios de Lingüística de la Universidad de Alicante. Alicante: Universidad de Alicante, p. 36.

Ducrot, Oswald. 1972 [1982]. Decir y no Decir. Barcelona: Anagrama.

Ducrot, Oswald. 1980. Les Échelles Argumentatives. Paris: Les Éditions du Minuit.

Englebretson, Robert, ed. 2007. Stancetaking in Discourse: Subjectivity, Evaluation, Interaction. Amsterdam and Philadelphia: John Benjamins.

Evans, Nicholas. 2007. Insubordination and its uses. In Finiteness. Theoretical and Empirical Approaches. Edited by Irina Nikolaeva. Oxford: Oxford University Press, pp. 366-431.

Evans, Nicholas, and Honoré Watanabe, eds. 2016a. Insubordination. Amsterdam: John Benjamins.

Evans, Nicholas, and Honoré Watanabe. 2016b. The dynamics of insubordination. In Insubordination. Edited by Nicholas Evans and Honoré Watanabe. Amsterdam: John Benjamins, pp. 1-38.

Fauconnier, Gilles. 1975. Pragmatic scales and logical structure. Linguistic Inquiry 6: 353-75.

Foolen, Ad. 2012. The Relevance of Emotion for Language and Linguistics. In Moving Ourselves, Moving Others. Motion and Emotion in Intersubjectivity, Consciousness and Language. Edited by Ad Foolen, Ulrike M. Lüdtke, Timothy P. Racine and Jordan Zlatev. Amsterdam: John Benjamins, pp. 349-68. 
Foolen, Ad. 2016. Expressives. In The Routledge Handbook on Semantics. Edited by Nick Riemer. London and New York: Taylor and Francis, pp. 473-90.

Fraser, Bruce. 2006. Towards a theory of discourse markers. In Approaches to Discourse Particles. Edited by Kerstin Fischer. Amsterdam: Elsevier, pp. 189-204.

Gras, Pedro. 2007. Gramática y pragmática de construcciones subordinadas introducidas por ni que en español: Un enfoque construccionista. In Actas del VI Congreso de Lingüística General: Santiago de Compostela, 3-7 de mayo de 2004/coord. por Pablo Cano López. Santiago de Compostela: Dialnet, Vol. 2.1, pp. 1609-20.

Gras, Pedro. 2011. Gramática de Construcciones en Interacción. Propuesta de un Modelo y Aplicación al Análisis de Estructuras Independientes con Marcas de Subordinación en Español. Doctoral dissertation, Universitat de Barcelona, Barcelona.

Gras, Pedro. 2016. Revisiting the functional typology of insubordination: Que-initial sentences in Spanish. In Insubordination. Edited by Nicholas Evans and Honoré Watanabe. Amsterdam: John Benjamins, pp. 113-44.

Gras, Pedro, and María Sol Sansiñena. 2015. An interactional account of discourse connective que-constructions in Spanish. Text and Talk 35: 505-29. [CrossRef]

Grundy, Peter. 2008. Doing Pragmatics. London: Hodder Education.

Huddleston, Rodney, and Geoffrey K. Pullum. 2002. The Cambridge Grammar of the English Language. Cambridge: Cambridge University Press.

Iwasaki, Shoichi. 1993. Functional transfer in the history of the Japanese language. In Japanese/Korean linguistics, 2nd ed. Edited by Patricia M. Clancy. Stanford: CSLI aLBAPublications, pp. 20-32.

Iwasaki, Shoichi. 2000. Suppressed assertion and the functions of the final-attributive in prose and poetry of Heian Japanese. In Textual Parameters in Older Languages. Edited by Susan Herring, Pieter van Reenen and Lene Schøsler. Amsterdam: John Benjamins, pp. 237-72.

Karttunen, Lauri, and Stanley Peters. 1975. Conventional implicature in Montague Grammar. Proceedings of the First Annual Meeting of the Berkeley Linguistic Society 1: 266-78.

Karttunen, Lauri, and Stanley Peters. 1979. Conventional implicature. In Syntax and Semantics II: Presupposition. Edited by Choon-Kyu Oh and David A. Dinneen. New York: Academic Press, pp. 1-56.

Kay, Paul. 1990. Even. Linguistics and Philosophy 13: 59-111. [CrossRef]

Lüdtke, Ulrike M. 2015. Introduction: From Logos to Dialogue. In Emotion in Language. Edited by Ulrike M. Lüdtke. Amsterdam: John Benjamins, pp. vii-xi.

Martin, Jim R., and Peter R. R. White. 2005. The Language of Evaluation. Appraisal in English. New York: Palgrave Macmillan.

Majid, Asifa. 2012. Current Emotion Research in the Language Sciences. Emotion Review 4: 432-43. [CrossRef]

Mithun, Marianne. 2008. The extension of dependency beyond the sentence. Language 84: 69-119. [CrossRef]

Porroche, Margarita. 2000a. Algunos aspectos del uso de que en el español conversacional (que como introductor de oraciones "independientes"). Círculo de Lingüística Aplicada a la Comunicación 3: 100-16.

Porroche, Margarita. 2000b. Aspectos del uso de ni como marcador discursivo. In Lengua, Discurso, Texto: I Simposio Internacional de Análisis del Discurso. Edited by José Jesús de Bustos Tovar. Madrid: Visor, vol. 1.

Porroche, Margarita. 2002. Las llamadas conjunciones como elementos de conexión en el español conversacional: Pues/pero. Círculo de Lingüística Aplicada a la Comunicación 9: 35-54.

Porroche, Margarita. 2003. Aspectos discursivos en el uso de algunas conjunciones españolas. Oralia 6: 259-82.

Porroche, Margarita. 2015. Sobre la marcación del discurso en español. Círculo de Lingüística Aplicada a la Comunicación 62: 10-31.

Real Academia Española y Asociación de Academias de la Lengua Española. 2009. Nueva Gramática de la Lengua Española. Madrid: Espasa.

Rodríguez Ramalle, Teresa. 2011. Sobre si y la organización del margen preverbal en español. Lingüística Española Actual (LEA) 33: 199-222.

Rodríguez Ramalle, Teresa. 2015. Las oraciones causales con que y como que y su interpretación en el discurso. Lenguas Modernas 45: $127-48$.

Sansiñena, María Sol. 2015. The Multiple Functional Load of que. An Interactional Approach to Insubordinate Complement Clauses in Spanish. Doctoral dissertation, Katholieke Universiteit van Leuven, Leuven, Belgium.

Sansiñena, María Sol, Hendrik de Smet, and Bert Cornillie. 2015. Between subordinate and insubordinate. Paths towards complementizer-initial main clauses. Journal of Pragmatics 77: 3-19. [CrossRef]

Schiffrin, Deborah. 1987. Discourse Markers. Cambridge: Cambridge University Press.

Schnoebelen, Tyler. 2012. Emotions are Relational: Positioning and the Use of Affective Linguistic Resources. Doctoral dissertation, Stanford University, Stanford, CA, USA.

Schwarz-Friesel, Monika. 2015. Language and Emotion. The Cognitive Linguistic Perspective. In Emotion in Language. Edited by Ulrike M. Lüdtke. Amsterdam: John Benjamins, pp. 157-73.

Thompson, Geoff, and Laura Alba-Juez. 2014. Evaluation in Context. Amsterdam: John Benjamins.

Tomkins, Silvan S. 1982. Affect Theory. In Emotion in the Human Face, 2nd ed. Edited by Paul Ekman, Wallace V. Friesen and Phoebe Ellsworth. Cambridge: Cambridge University Press, pp. 353-95.

Yates, Jean. 2006. Algunas Partículas Escalares del Español y su Traducción al Inglés. Doctoral dissertation, Universidad Autónoma de Madrid, Madrid, Spain. 